\title{
Development of Competency-Based Assessment Model Welding Practices for Vocational School Students
}

\author{
Zakariya Ahmad*, Zainur Rofiq \\ Mechanical Engineering Education, Yogyakarta State University, Yogyakarta, Indonesia \\ *Corresponding author: zakariyaahmad.2018@student.uny.ac.id
}

Received December 04, 2019; Revised January 04, 2020; Accepted January 15, 2020

\begin{abstract}
Assessment is the final acquisition of student work to measure competence. Therefore we need an assessment model that can describe the results of achieving student competence. In this study, the aim is to design an assessment model that will be used in the learning process in welding practices. The product development procedure uses the steps proposed by Borg \& Gall. Research samples are experts in the field of welding and welding subject teachers. Data obtained from interviews and observations then analyzed using qualitative descriptive analysis techniques. The results of this study generally produce an assessment model on welding practices for vocational students consisting of 5 levels, namely: (1) welding parameters, (2) machine settings and work safety, (3) make a welding line, (4) grooves, and (5) the standard of the American Welding Society. The valuation model is completed with a rating scheme, level of assessment, aspects of assessment, assessment indicators, appraisal description, assessment score, and evaluation.
\end{abstract}

Keywords: assessment models, welding practices, developing assessment models, welding assessments

Cite This Article: Zakariya Ahmad, and Zainur Rofiq, "Development of Competency-Based Assessment Model Welding Practices for Vocational School Students." American Journal of Educational Research, vol. 8, no. 1 (2020): 29-34. doi: 10.12691/education-8-1-5.

\section{Introduction}

Vocational education is an education that emphasizes academic learning activities and also practical learning so that students can have stock in facing the times. The purpose of the Vocational High School (VHS) is realized with a curriculum structure that contains three programs, namely normative, adaptive, and productive programs [1]. Vocational Schools, as one of the formal educational institutions, endeavor to advance the field of expertise education, especially in competency expertise and have implemented competency-based learning [2]. It is intended that learning materials, especially on productive subjects such as welding subjects, reflect the need to achieve the competencies required by the world of work. Welding subjects are one of the essential competencies that must be mastered by vocational graduates in the field of mechanical engineering expertise in welding. Following the decision of the Director-General of Primary and Secondary Education, the Ministry of Education and Culture regarding the spectrum of Vocational high school skills [3]. In order to achieve these objectives, learning Groove welding, especially $1 \mathrm{G}, 2 \mathrm{G}$, and $3 \mathrm{G}$, which is implemented in schools, must be implemented optimally. To support the achievement objectives of the learning process, appropriate strategies and assessment models are needed to measure the competency of student achievement, especially in welding subjects.
Following the concept of learning in vocational schools, expertise competencies are designed and applied in the form of working directly through the production process as a vehicle for learning. Learning is not just remembering facts but integrated with assessing students so that it can be used as an assessment to find out student success as a whole [4]. Through education, every individual must be provided with various lifelong learning opportunities, both to increase knowledge, skills, and attitudes, as well as to be able to adjust to a complex and interdependent world. For this reason, relevant education must rely on the four pillars of education, namely learning to know learners learn knowledge, learning to do namely students use their knowledge to develop skills, learning to be namely learners learn to use their knowledge and skills for life, and learning to live together namely students learn to realize that there is interdependence so that mutual respect between human beings is needed. Thus, vocational education at this time must be able to equip each student with knowledge, skills, and values and attitudes, where the learning process does not merely reflect knowledge but reflects the four pillars above. Through these four pillars, competence can be formed [5].

Competence is knowledge, skills, attitudes, and values that are owned and controlled by students that can be displayed clearly in solving/completing tasks in life. So someone is said to be competent when it is formed an ability that can be relied upon in facing the demands of life. In other words, competence is built so that each individual can be survived in facing a life full of 
challenges in this global era. The vocational competency test is a recognition of the world of work on student competencies [6]. In general, competency tests are all activities to give, obtain, improve, and develop work competency, productivity, discipline, attitude, and work ethic at a specific skill and expertise level according to the level and qualifications of position or occupation [7]. Competency testing is carried out following the expertise competencies that students already have and has received official recognition from the industrial world so that the results of student competency testing can be a valid recognition of competency skills that have been mastered through the process of competency testing.

The competency-based approach to expertise designed following the VHS curriculum has implications for the technical assessment of learning outcomes. For students to be able to show the real quality of expertise by showing a certificate of expertise as a model of implementing competency expertise [8]. Competency skills activities have a responsibility so that students can do a job following the material or competencies that have been taught in the learning process. In the process of competency testing, teachers should be able to facilitate, encourage, and provide real studies following what will happen in the world of work or industry [9]. For this reason, the assessment model is designed according to expertise or competency-based competencies. The implementation of progress assessment and competencybased learning outcomes is directed to measure and assess learners' capabilities in terms of knowledge, skills, and attitudes. Internal assessment of the learning outcomes of students conducted by teachers on behalf of the school to assess the competence of students at a certain level at the time and end of learning [10].

The assessment results can be in the form of qualitative values (narrative statements in words) and quantitative values (in the form of numbers). Measurements related to the process of finding or determining the quantitative value explicitly in the context of practical learning, assessment is carried out to determine the progress and learning outcomes of students, diagnose learning difficulties, provide feedback/improvement of teaching and learning, and determining graduation. Through assessment, accurate information can be obtained about the implementation of the learning and learning success of students, teachers, and the learning process itself. Assessment, which is the final result of the acquisition of students before and after taking a type of work or assignments that have been given by the teacher to students, assessment in the learning process has three assessments, namely in the form of affective, cognitive and psychomotor assessments [11]. The assessment of skills that exist in the competence of mechanical engineering expertise, one of which assesses the competency of expertise, where expertise competency is one of the students' performances in obtaining a certificate as an assessment of student competencies, especially in the field of welding. The results of competency testing are something students have in facing the era of revolution to be competitive [12].

In the testing of vocational competencies, especially welding in VHS Negeri 1 Magelang still has shortcomings; in this case, the assessment is an assessment by showing work preparation and student work without assessing the competency process carried out. The difficulty faced in deciding to provide an assessment of vocational competence in the field of welding is to determine the value of student work because the existing assessments have not been able to infer student competencies. While the demands of the industrial world for competence can produce competent students following their fields of expertise. Therefore it is necessary to have a more effective assessment and to follow the needs of the industrial world so that it is necessary to develop an assessment based on the industrial world and be able to conclude that students are genuinely competent following the area of welding expertise. Based on these problems so that it is necessary to solve the problems faced in providing assessment, researchers are interested in researching the development of assessment models with the title "Development of Competency-Based Assessment Model Welding Practices for Vocational School Students" especially in welding Shield Metal Arc Welding (SMAW) Groove 1-3. This product is made following the needs of teachers of welding techniques to assess student competencies to help achieve the objectives of vocational competency-based assessment.

\section{Research methodology}

The development model in this study uses the Borg and Gall procedure. Based on the model, several steps are adjusted as the direction of development of the assessment model that will be generated, the steps of developing the assessment model are taken as follows: (1) determining the topic or focus of the research, (2) making a needs analysis instrument, (3) gathering data, (4) product manufacture, and (5) final product, the development steps can be seen in the following Figure 1:

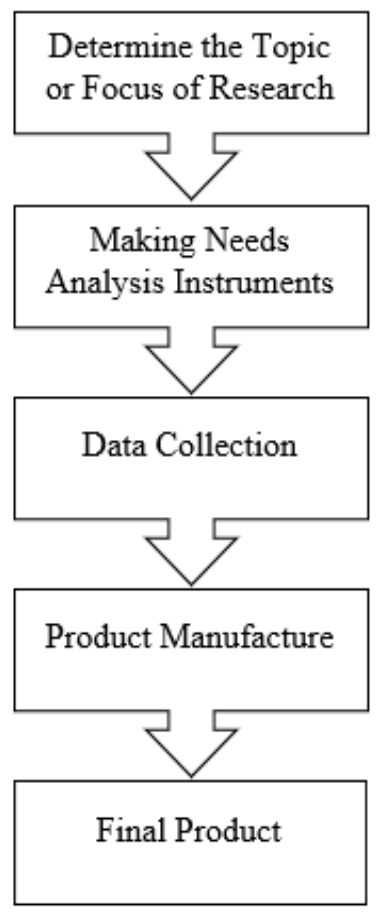

Figure 1. Development Steps Undertaken 
Data obtained from interviews and observations were then analyzed using qualitative descriptive analysis techniques. Qualitative research is research that seeks to build the views of people studied in detail and is formed with words, holistic (comprehensive and in-depth) and complicated [13]. The process of collecting qualitative data that focuses on interviews and participatory observation makes the data analysis in the form of textual analysis of the results of transcripts or unstructured field notes.

\section{Subjects and Research Sites}

Table 1. Subjects and Places

\begin{tabular}{|l|l|}
\hline Subject & The Place \\
\hline Welding Expert Lecturer & Yogyakarta State University \\
\hline Teacher & VHS Negeri 1 Magelang \\
\hline
\end{tabular}

\section{Research Results and Discussion}

Measuring student competency in welding practices is a step taken by the teacher to conduct an assessment. In the testing of vocational competencies, especially welding in VHS Negeri 1 Magelang still has shortcomings; in this case, the assessment is an assessment by showing work preparation and student work without assessing the competency process carried out. Based on an analysis of the existing welding practice assessment instruments in the field, the form of the assessment instruments only assesses based on preparation and results, and there is no assessment that assesses the process is based on competence. Weaknesses in the assessment system can lead to the unknown achievement of student practice competencies. Whereas for work in the industry, students are required to have competencies following their fields. Besides, it will make students difficult in obtaining competency certificates because what is assessed is their skill competency. This will later affect the grading of student work so that assessment becomes more subjective. The difficulty faced in deciding to provide an assessment of vocational competence in the field of welding is to determine the value of student work because the existing assessments have not been able to infer student competencies. While the demands of the industrial world for competence can produce competent students following their fields of expertise. Therefore it is necessary to have a more effective assessment and to follow the needs of the industrial world so that it is necessary to develop an assessment based on the industrial world and be able to conclude that students are genuinely competent following the area of welding expertise. Based on these problems, it is necessary to solve the problems faced in providing an assessment, researchers interested in making an assessment model. The assessment model that the researchers designed consisted of 5 levels, namely: (1) welding parameters, (2) machine settings and work safety, (3) manufacturing welded tooth lines, (4) grooves, and (5) American Welding Society standards. The valuation model is completed with a rating scheme, level of assessment, aspects of assessment, assessment indicators, appraisal description, assessment score, and evaluation. This assessment model is made according to the needs of the welding technique teacher and asks for advice and input from experts in the field of welding to assess student competencies in welding practices and help achieve the objectives of vocational competency-based assessment.

\subsection{Rating Scheme}

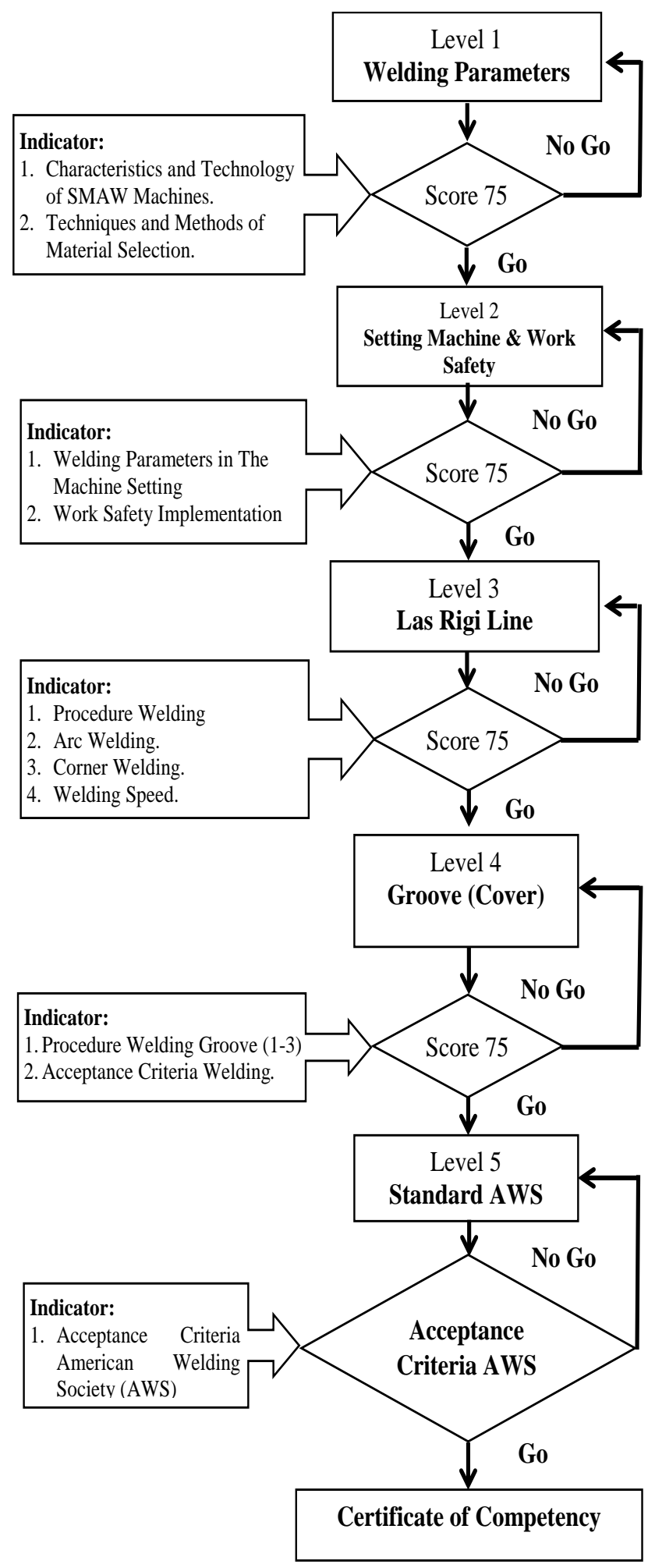

Figure 2. Rating Scheme 


\subsection{Level-1 Welding Assessment}

Table 2. Level 1 Assessment

\begin{tabular}{|c|c|c|c|}
\hline Level & Aspect & Indicator & Description \\
\hline \multirow{12}{*}{ Level 1} & \multirow{12}{*}{$\begin{array}{l}\text { Parameter } \\
\text { (Can use } \\
\text { applications } \\
\text { such as Welding } \\
\text { Calculator } \\
\text { Boehler and } \\
\text { Miller) }\end{array}$} & \multirow{12}{*}{$\begin{array}{l}\text { 1. Characteristics } \\
\text { and technology of } \\
\text { SMAW welding } \\
\text { machines } \\
\text { 2. Techniques and } \\
\text { methods of } \\
\text { material selection }\end{array}$} & Can determine the type of joint? (single/double weld) \\
\hline & & & $\begin{array}{l}\text { Can determine the welding technique according to the procedure? (whipping, curved weave, } \\
\text { zigzag) }\end{array}$ \\
\hline & & & Can simulate vertical progress? (up/down) \\
\hline & & & Able to position welding according to procedure? \\
\hline & & & Analyze the type of material used? \\
\hline & & & Being able to sort the type of electrodes used? \\
\hline & & & Know the electrode specifications according to the procedure? \\
\hline & & & Being able to choose the type of engine current? (AC/DC) \\
\hline & & & Know the engine polarity? (DCEP/DCEN) \\
\hline & & & Able to adjust the engine amperage used according to workpiece? \\
\hline & & & Know the voltage used according to the procedure? \\
\hline & & & Able to adjust the welding speed in accordance with workpiece? \\
\hline \multicolumn{3}{|c|}{$\begin{array}{l}\text { Score }(0-25) \\
\text { PASS/NOT PASS } \\
{ }^{*} \text { Cross the unnecessary ones }\end{array}$} & Student Evaluation: \\
\hline \multicolumn{3}{|c|}{ Remedial } & 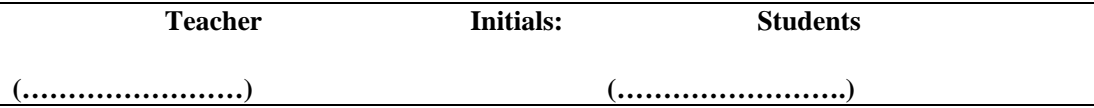 \\
\hline
\end{tabular}

\subsection{Level-2 Welding Assessment}

Table 3. Level 2 Assessment

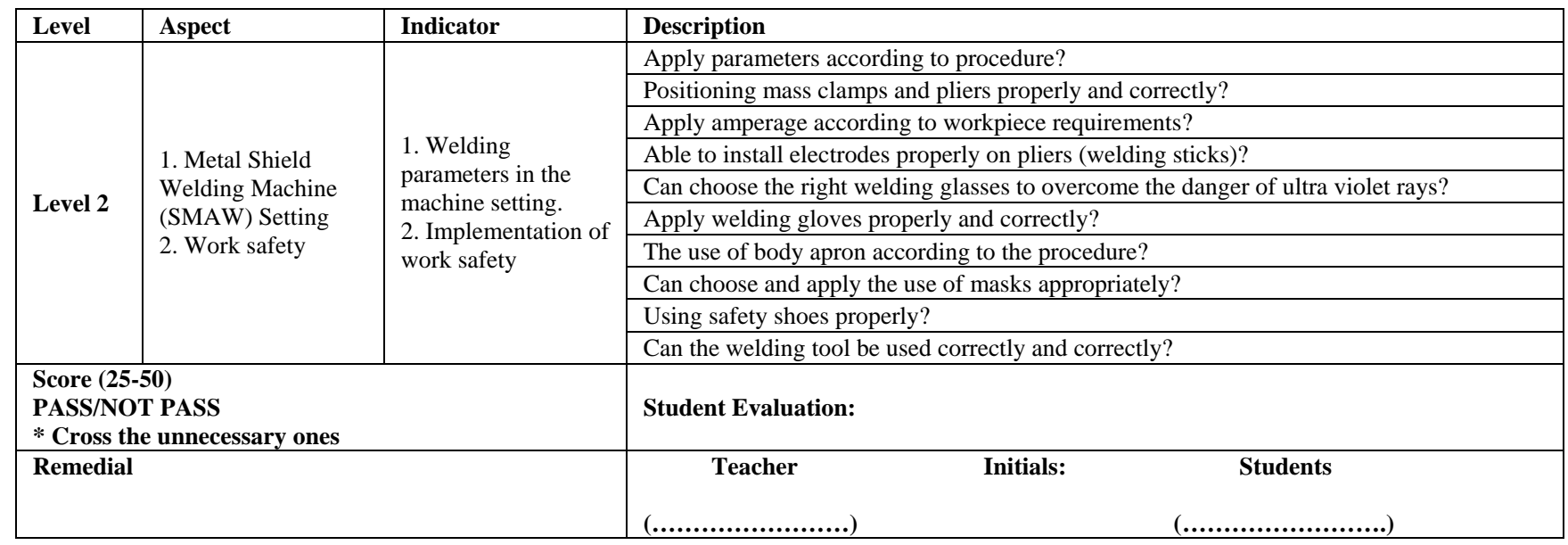

\subsection{Level-3 Welding Assessment}

Table 4. Level 3 Assessment

\begin{tabular}{|c|c|c|c|}
\hline Level & Aspect & Indicator & Description \\
\hline \multirow{15}{*}{ Level 3} & \multirow{15}{*}{$\begin{array}{l}\text { 1. Welding Line } \\
\text { (Preparation). } \\
\text { 2. Welding Line } \\
\text { (Welding } \\
\text { Process). }\end{array}$} & \multirow{15}{*}{$\begin{array}{l}\text { 1. Prosedur welding } \\
\text { 2. Arc welding. } \\
\text { 3. Corner welding. } \\
\text { 4. Welding speed. }\end{array}$} & Do welding according to parameters? \\
\hline & & & Do welding according to machine settings? \\
\hline & & & Able to identify working drawings/welding symbols? \\
\hline & & & Ensuring the readiness of the welding machine? \\
\hline & & & Ensuring the readiness of auxiliary equipment according to parameters? \\
\hline & & & Ensuring material/workpiece readiness? \\
\hline & & & Make sure the surface of the weld is free of dirt and rust? \\
\hline & & & Ensure the position of the oblique workpiece according to procedure? \\
\hline & & & Perform Tack Welding (Welding point) according to procedure \\
\hline & & & Check the direction of welding motion according to the procedure? \\
\hline & & & Maintain the condition of the Arc welding according to the procedure \\
\hline & & & Maintain the stability of the welding angle (Corner Welding) according to the procedure \\
\hline & & & Ensure that the welded joint at the start stop is free of welding defects \\
\hline & & & Clean the slag \\
\hline & & & Maintaining the quality of welding according to acceptance criteria \\
\hline \multicolumn{3}{|c|}{$\begin{array}{l}\text { Score }(50-75) \\
\text { PASS/NOT PASS } \\
\text { * Cross the unnecessary ones }\end{array}$} & Student Evaluation: \\
\hline \multicolumn{3}{|c|}{ Remedial } & 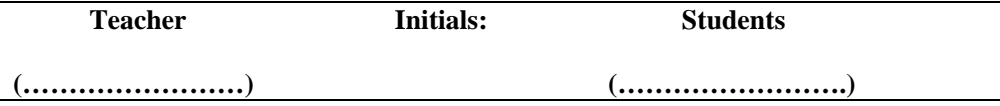 \\
\hline
\end{tabular}




\subsection{Level-4 Welding Assessment}

Table 5. Level 4 Assessment

\begin{tabular}{|c|c|c|c|}
\hline Level & Aspect & Indicator & Description \\
\hline \multirow{15}{*}{ Level 4} & \multirow{15}{*}{$\begin{array}{l}\text { 1. Groove Welding } \\
\text { (Preparation) } \\
2 \text {. Welding Groove } \\
\text { (Welding Process). } \\
\text { Cover }\end{array}$} & \multirow{15}{*}{$\begin{array}{l}\text { 1. Welding } \\
\text { procedure - Groove } \\
\text { 2. Acceptance } \\
\text { criteria welding. }\end{array}$} & Do welding according to parameters? \\
\hline & & & Do welding according to machine settings? \\
\hline & & & Able to identify working drawings/welding symbols? \\
\hline & & & Ensuring the readiness of the welding machine? \\
\hline & & & Ensuring the readiness of auxiliary equipment according to parameters? \\
\hline & & & Ensuring material/workpiece readiness? \\
\hline & & & Make sure the surface of the weld is free of dirt and rust? \\
\hline & & & Ensure the position of the oblique workpiece according to procedure? \\
\hline & & & Perform Tack Welding (Welding point) according to procedure \\
\hline & & & Check the direction of welding motion according to the procedure? \\
\hline & & & Maintain the condition of the Arc welding according to the procedure \\
\hline & & & Maintain the stability of the welding angle (Corner Welding) according to the procedure \\
\hline & & & Ensure that the welded joint at the start stop is free of welding defects \\
\hline & & & Clean the slag \\
\hline & & & Maintaining the quality of welding according to acceptance criteria \\
\hline \multicolumn{3}{|c|}{$\begin{array}{l}\text { Score }(75-100) \\
\text { PASS/NOT PASS } \\
\text { * Cross the unnecessary ones }\end{array}$} & Student Evaluation: \\
\hline \multicolumn{3}{|c|}{ Remedial } & $\begin{array}{cc}\text { Teacher } & \text { Initials: } \\
(\ldots \ldots \ldots \ldots \ldots \ldots \ldots \ldots) & \\
\end{array}$ \\
\hline
\end{tabular}

\subsection{Level-5 Standard American Welding Standard (AWS) Welding Assessment}

Table 6. Level 5 Assessment of the American Welding Society (AWS)

\begin{tabular}{|c|l|c|}
\hline No & Aspect Criteria Description & Acquisition \\
\hline 1 & Has surface slag, smoke and spatter been removed from 99\% of the joint and surrounding area & \\
\hline 2 & Are stray arc strikes absent & \\
\hline 3 & Is the bead width uniform and regular (Allow 2mm variation) & \\
\hline 4 & Are all stop/starts smooth on the capping layer /Allow 1.5mm variation between the stop and restart & \\
\hline 5 & Are all stop/starts smooth on the penetration / Allow 1.5mm variation between the stop and restart & \\
\hline 6 & Is the weld metal completely free from visual inclusions (Slag,Tungsten,etc) & \\
\hline 7 & Is the weld metal completely free from surface porosity & \\
\hline 8 & Is the welded joint free from undercut? (disregard depth of 0.5mm or less) & \\
\hline 9 & Is the welded joint free from incomplete penetration or root fusion & \\
\hline 10 & Is the welded joint free from excessive penetration (greater than 2mm) & \\
\hline 11 & Is the welded joint free from excessive root concavity or suck back (disregard depth of 0.5mm or less) & \\
\hline 12 & Is the butt weld groove completely filled (Under fill not undercut) & \\
\hline 13 & Is the weld joint free from excessive face reinforcement (Greater than 2.5mm) & \\
\hline 14 & Is the joint free from angular distortion (Greater than 3 degrees) & \\
\hline 15 & Is the joint free from linear misalignment? (greater than 1mm) & \\
\hline \multicolumn{2}{|l}{ Total Score } & \\
\hline
\end{tabular}

Table 7. AWS Standard Assessment Criteria

\begin{tabular}{|c|l|c|}
\hline No & Aspect Criteria Description & Score Max \\
\hline 1 & Has surface slag, smoke and spatter been removed from 99\% of the joint and surrounding area & 0.2 \\
\hline 2 & Are stray arc strikes absent & 0.2 \\
\hline 3 & Is the bead width uniform and regular (Allow 2mm variation) & 0.3 \\
\hline 4 & Are all stop/starts smooth on the capping layer / Allow 1.5mm variation between the stop and restart & 0.2 \\
\hline 5 & Are all stop/starts smooth on the penetration / Allow 1.5mm variation between the stop and restart & 0.3 \\
\hline 6 & Is the weld metal completely free from visual inclusions (Slag,Tungsten,etc) & 0.3 \\
\hline 7 & Is the weld metal completely free from surface porosity & 0.3 \\
\hline 8 & Is the welded joint free from undercut? (disregard depth of 0.5mm or less) & 0.3 \\
\hline 9 & Is the welded joint free from incomplete penetration or root fusion & 0.3 \\
\hline 10 & Is the welded joint free from excessive penetration (greater than 2mm) & 0.3 \\
\hline 11 & Is the welded joint free from excessive root concavity or suck back (disregard depth of 0.5mm or less) & 0.3 \\
\hline 12 & Is the butt weld groove completely filled (Under fill not undercut) & 0.3 \\
\hline 13 & Is the weld joint free from excessive face reinforcement (Greater than 2.5mm) & 0.3 \\
\hline 14 & Is the joint free from angular distortion (Greater than 3 degrees) & 0.2 \\
\hline 15 & Is the joint free from linear misalignment? (greater than 1mm) & 0.2 \\
\hline Total Value & $\mathbf{4}$ \\
\hline
\end{tabular}




\section{Research Limitations}

This study only made a competency-based welding practice assessment model without conducting an in-depth validation of the product. Besides, this research was only conducted at one school, namely VHS Negeri 1 Magelang.

\section{Conclusion}

This study can provide an overview of competencybased assessment, especially in learning the practice of welding Shield Metal Arc Welding (SMAW) Groove 1 to Groove 3 for vocational students following the demands of the industrial world. The results of this study resulted in an assessment model on welding practices for vocational students consisting of 5 levels, namely: (1) welding parameters, (2) machine settings and work safety, (3) making welding rigans, (4) grooves, and (5) the American Welding Society-AWS standard. The valuation model is completed with a rating scheme, level of assessment, aspects of assessment, assessment indicators, appraisal description, assessment score, and evaluation. With this research, it is expected that the welding competency assessment can run according to the demands of industry competence so that vocational graduates after graduation will more easily enter the industrial world.

\section{Acknowledgements}

The authors express their sincere thanks and appreciation to all reviewers who contributed their expertise and time to review the manuscript and evaluate this article.

\section{References}

[1] Susanto, H. (2012). Faktor-faktor yang mempengaruhi kinerja guru sekolah menengah kejuruan. Jurnal Pendidikan Vokasi, 197-212.

[2] Hamalik, Oemar. (2015). Kurikulum dan pembelajaran. Jakarta: Bumi Aksara

[3] Peraturan Direktur Jenderal Pendidikan dan Menengah Nomor 06/D.D5/KK/2018. (2018). Tentang spektrum keahlian sekolah menengah kejuruan (smk)/madrasah aliyah kejuruan (MAK). Jakarta

[4] Nusrotus Sa'idah, H. D. (2018). Model penilaian otentik berbasis kecakapan hidup siswa dalam pembelajaran bahasa indonesia. Litera, 213-227.

[5] Dantes, N. (2008). Hakikat asesmen otentik sebagai penilaian proses dan produk dalam pembelajaran yang berbasis kompetensi. Bali: In House Training (IHT) SMA Negeri 1 Kuta Utara.

[6] Suranto, Muhyadi, \& Mardapi, D. (2014). Pengembangan instrumen evaluasi uji kompetensi keahlian (UKK) administrasi perkantoran di SMK. Jurnal penelitian dan evaluasi pendidikan, 98-114.

[7] Awaludin, H. (2006). Peraturan Pemerintah Republik Indonesia. Jakarta: Menteri Hukum Dan Hak Asasi Manusia.

[8] Taruno, D. L. (2014). Model uji kompetensi keahlian instalasi listrik. Jurnal Kependidikan, 103-116.

[9] Wibowo, N. (2016). Upaya memperkecil kesenjangan kompetensi lulusan sekolah menengah kejuruan dengan tuntutan dunia industri. Jurnal Pendidikan Teknologi dan Kejuruan, 45-50.

[10] Sumaryanta. (2010). Kajian kurikulum pendidikan matematika. Yogyakarta: Universitas PGRI Yogyakarta.

[11] Nyberg, A. J. (2014). Resource-based perspectives on unit-level human capital: A review and integration. Journal of management, 316-346.

[12] Boon, R. E. (2017). Integrating strategic human capital and strategic human resource management. The international journal of human resource management, 34-67.

[13] Tohirin. (2013). Metode penelitian kualitatif dalam pendidikan dan bimbingan konseling. Jakarta: PT Raja Grafindo Persada.

(C) The Author(s) 2020. This article is an open access article distributed under the terms and conditions of the Creative Commons Attribution (CC BY) license (http://creativecommons.org/licenses/by/4.0/). 